\title{
O ZONEAMENTO AMBIENTAL GEOMORFOLÓGICO COMO MÉTODO PARA PLANEJAR A INFRAESTRUTURA VERDE EM ÁREAS DENSAMENTE URBANIZADAS
}

THE GEOMORPHOLOGICAL ENVIRONMENTAL ZONING AS METHOD FOR GREEN INFRASTRUCTURE PLANNING IN DENSELY URBANIZED AREAS

\section{RAmón STOCK BonZI}

Mestre pela FAUUSP, especialista em Arquitetura da Paisagem pelo Senac Santa Cecília e em Meio Ambiente e Sociedade pela FESPSP. E-mail: rsb@usp.br

\section{RESUMO}

A noção de Infraestrutura Verde vem sendo amplamente aceita nos campos da arquitetura da paisagem e do urbanismo. No entanto, a sua aplicação em áreas densamente urbanizadas carece de métodos adequados, uma vez que o conceito surgiu em um contexto muito diferente, o espraiamento norte-americano. Este trabalho investiga como a proposta de zoneamento ambiental baseado nos processos naturais e na análise geomorfológica pode embasar cientificamente a aplicação da Infraestrutura Verde. Para isso identificamos os processos naturais predominantes em cada zona ambiental e também os processos mimetizados ou incentivados por cada tipologia paisagística. Conclui-se que a análise das formas do relevo permite identificar que tipologias são indicadas para cada compartimento do relevo, o que colabora para a harmonização entre as dinâmicas da base biofísica e a ocupação humana.

Palavras-chave: Infraestrutura Verde; Zoneamento Ambiental; Processos naturais; Análise geomorfológica; Tipologias Paisagísticas.

\section{ABSTRACT}

The concept of Green Infrastructure has been widely accepted in the fields of landscape architecture and urbanism. However, its application in densely urbanized areas lacks adequate methods, once the concept arose in a very different context, the urban sprawl in the United States. This work investigates how the proposal for environmental 
zoning based on natural processes and geomorphological analysis can scientifically support the implementation of the Green Infrastructure. Thus, to do so, it was identified natural processes prevailing in each environmental area and also mimicked processes or encouraged by each landscape typology. It was concluded that the analysis of the forms of relief identifies which typologies are suitable for each relief compartment, which contributes to the harmonization between the dynamics of the biophysical base and the human occupation.

Keywords: Green Infrastructure; Environmental Zoning; Natural Processes; Geomorphological Analysis; Landscape Typologies.

\section{INTRODUÇÃO}

Ainda que seja crescente a percepção de que os projetos de paisagem e de urbanismo devem estar atentos aos processos naturais e aos problemas ambientais urbanos, observa-se que na prática muitas das intervenções tidas como "ecológicas" carecem de embasamento teórico e, principalmente, de conhecimento e experiência técnica, desde o projeto até a sua implantação.

Mesmo sendo considerada a vanguarda do planejamento da paisagem e da intervenção urbana ecologicamente informada, percebe-se que a Infraestrutura Verde ${ }^{1}$ também não foge à regra. Contrastando com a clareza de seu objetivo principal (conciliar desenvolvimento com a conservação da natureza por meio de espaços abertos que fornecem serviços ambientais para a cidade ao mesmo tempo em que protegem a

\footnotetext{
1 O termo Infraestrutura Verde surgiu em 1994, em relatório da Comissão de Greenways da Flórida, em que se defendia que os sistemas naturais são componentes de nossa infraestrutura tão ou mais importantes do que a infraestrutura tradicional - a chamada "infraestrutura cinza", relativa a serviços como energia, transporte, abastecimento e coleta de esgoto, que em última análise possibilitam o funcionamento dos assentamentos humanos tais como os conhecemos (FIREHOCK, 2010). Segundo Benedict e McMahon, a Infraestrutura Verde é tanto um conceito de configuração espacial (rede de áreas verdes interconectadas) quanto a designação de um processo (planejamento sistemático e estratégico para conciliar conservação da natureza e uso do solo).Para Cormier e Pellegrino, a Infraestrutura Verde é "uma maneira de reconhecer e aproveitar os serviços que a natureza pode realizar no ambiente urbano" (2008, p.128).
} 
biodiversidade) não há até o momento uma metodologia própria para guiar o seu planejamento, o que vem gerando distorções em sua aplicação². Essa lacuna se agrava quando a intervenção se dá em área densamente urbanizada, visto que a noção de Infraestrutura Verde surgiu em contexto muitíssimo diferente: o espraiamento norteamericano pós-segunda guerra mundial.

Este artigo revisita a dissertação, "Andar sobre Água Preta: a aplicação da Infraestrutura Verde em áreas densamente urbanizadas", para apresentar o Zoneamento Ambiental baseado nos processos naturais como arcabouço teórico capaz de embasar cientificamente a aplicação da Infraestrutura Verde em áreas consolidadas. O método consiste na exposição do Zoneamento Ambiental por meio da análise geomorfológica, seguida da revisão das tipologias paisagísticas. Finalizada essas etapas metodológicas, cruza-se a proposta de Zoneamento Ambiental com os atributos de cada tipologia, o que permite apontar critérios claros para sua espacialização, contribuindo assim para que a sociedade mantenha certa estabilidade de sua base biofísica e para que a Infraestrutura Verde apresente seu máximo desempenho. É apresentado um estudo de caso para demonstrar a proposta teórica.

\section{UM CONCEITO DE GEOMORFOLOGIA A SERVIÇO DA INFRAESTRUTURA VERDE}

Schutzer (2004, 2012a, 2012b) aponta para uma nova abordagem no planejamento ecológico da paisagem: o zoneamento ambiental com vistas à preservação da qualidade dos processos naturais dentro do ambiente urbano. $O$ zoneamento ambiental parte

\footnotetext{
${ }^{2}$ A aplicação da Infraestrutura Verde quase sempre recorre à Ecologia da Paisagem. No entanto, em áreas densamente urbanizadas, a aplicação da ecologia da paisagem fica muito limitada já que a rigor sequer existem os elementos necessários (matriz, mancha e corredor) para a configuração de um mosaico da paisagem, padrão estrutural do qual partem as análises da disciplina. Para Forman, uma das maiores autoridades da landscape ecology, a ecologia da paisagem deve perseguir quatro padrões indispensáveis: grandes manchas de vegetação natural, amplos corredores vegetados ao longo de cursos d'água, conectividade para o fluxo de espécies-chave entre as pequenas e as grandes manchas de vegetação e pequenos pedaços heterogêneos de natureza permeando áreas urbanizadas (1995. P.140). Evidentemente, um cenário muito diferente daquele encontrado em áreas densamente urbanizadas.
} 
dos três níveis de análise geomorfológica³ propostos por Aziz Ab'Sáber (1969) - compartimentação do relevo, estrutura superficial da paisagem e fisiologia da paisagem - e gera um mapeamento que sugere a configuração espacial e funcional adequada para a convivência entre ocupação humana e processos naturais, como explica Schutzer:

Através do reconhecimento dos processos de funcionamento da paisagem natural poder-se-ia estabelecer premissas de atuação segundo as potencialidades natural e urbana de cada compartimento delineado e, assim, obter como resultado uma primeira aproximação a que estamos chamando de zoneamento ambiental com base nos processos naturais. Esses processos são basicamente os que se referem às dinâmicas do clima (evaporação, evapotranspiração, emissividade de calor, precipitação, movimentação do ar) e da água (escoamento superficial, infiltração, percolação, filtragem e armazenamento) (2012a, p.16).

Esse método de análise é capaz de subsidiar o desenho urbano com a leitura estratégica do relevo para a tomada de decisão sobre os espaços a ocupar ou a preservar. Como evolução do conceito de compartimentação do relevo ${ }^{4}$, a compartimentação ambiental foi desenvolvida especificamente para ser aplicada em áreas de ocupação humana mais densa (Schutzer, 2012c, p. 23). Ela introduz a ideia de valores de uso e de ocupação do relevo para a sociedade, apontando a aptidão ou a fragilidade de cada compartimento em responder a funções urbanas.

O conceito de estrutura superficial da paisagem ${ }^{5}$ verifica as características físicas dos solos e depósitos superficiais que revestem os compartimentos de relevo e como se

${ }^{3}$ Ab'Sáber define a Geomorfologia como "um campo científico que cuida do entendimento da compartimentação da topografia regional, assim como da caracterização e descrição, tão exatas quanto possíveis, das formas de relevo de cada um dos compartimentos estudados" (1969).

${ }^{4}$ A compartimentação do relevo é uma técnica de abordagem do relevo que consiste em diferenciar conjuntos do relevo com base em critérios como forma, processos modeladores ou domínio altimétrico. As classificações podem variar de acordo com os critérios adotados (morfoescultura, morfoestrutura e morfologia), o táxon e a escala de análise.

5 Segundo Ab'Sáber (1969) a estrutura superficial da paisagem é a "epiderme da paisagem", o resultado cumulativo dos eventos quaternários, isto é, do período geológico que abrange os últimos 1.6-1.8 miIhões de anos. Foi neste intervalo cronológico que aconteceram os eventos climáticos que deram forma à camada mais superficial da Terra, notadamente aos regimes fluviais, solos e depósitos superficiais. 
comportam frente aos processos naturais e humanos. Permite a avaliação de solos e depósitos enquanto suporte para a ocupação (qualidade como fundação, aptidão para implantação de loteamentos e infraestruturas, drenabilidade), como fonte de recurso natural (material de construção, fornecimento de água, esgotamento sanitário, agricultura), como local para o desenvolvimento e conservação da fauna, flora e para a ocorrência de serviços ambientais (purificação da água, regeneração do ar, manutenção de microclima, por exemplo). Sua análise informa sobre a qualidade dos processos naturais. Apoiada na fisiologia da paisagem ${ }^{6}$, isto é, no funcionamento das dinâmicas naturais e de suas imbricações com as atividades humanas, é possível identificar áreas para a ocupação, áreas com restrição e áreas inadequadas - seja por riscos de deslizamento, inundação ou contaminação do solo.

Há compartimentos que colaboram mais efetivamente com a preservação de valores geoecológicos tais como recursos (flora, fauna, água e solos) e processos naturais (infiltração, percolação, evapotranspiração e escoamento superficial) (2012b, p. 239), (2012c, p. 23). Esses espaços estratégicos são definidos como compartimentos ambientais estruturantes da paisagem e podem ser indutores, receptores ou transmissores de processos naturais 7 . A compartimentação ambiental da paisagem e o zoneamento ambiental fornecem subsídios para que a sociedade mantenha certa estabilidade de sua base biofísica. Ao contrário de outras propostas de cunho ambiental, é propositiva e trabalha com conceitos e categorias de pensamento que não são de todo estranhas para aqueles que planejam, projetam e intervém na paisagem.

\section{ZONEAMENTO AMBIENTAL NO SÍTIO URBANO DE SÃO PAULO}

Do cruzamento das três categorias de análise geomorfológica é possível realizar a divisão em zonas de acordo com a potencialidade para a manutenção e o desenvol-

\footnotetext{
${ }^{6}$ A fisiologia da paisagem estuda a estrutura superficial da paisagem em seu momento presente, observando a sua funcionalidade atual e global no que tange às dinâmicas hidrológicas e climáticas, aos processos biogênicos e à influência antrópica predatória (AB'SÁBER, 1969).

7 Divisores de água de bacias hidrográficas, por exemplo, são indutores de processos naturais já que definem a intensidade e a direção do escoamento superficial. Fundos de vale são receptores, uma vez que são os espaços para os quais converge a água precipitada pela chuva em toda a bacia hidrográfica, seja por infiltração, percolação ou escoamento superficial. As vertentes são receptoras, mas também transmissoras de processos, pois interligam compartimentos ambientais estruturantes.
} 
vimento dos processos naturais ${ }^{8}$.

Partindo da individualização dos elementos topográficos realizada por Ab'Sáber (figura 1) e tendo em vista as potencialidades ambientais e urbanas frente os processos naturais e suas qualidades para a ocupação, Schutzer (2012a, p.197) identifica quatro compartimentos de relevo no setor entre os rios Tietê e Pinheiros, ao longo do Espigão Central (fig. 2). Cada compartimento possui características físicas principais e processos naturais predominantes (dinâmicas hidrológica e do clima, sobretudo) e qualidades para a ocupação.

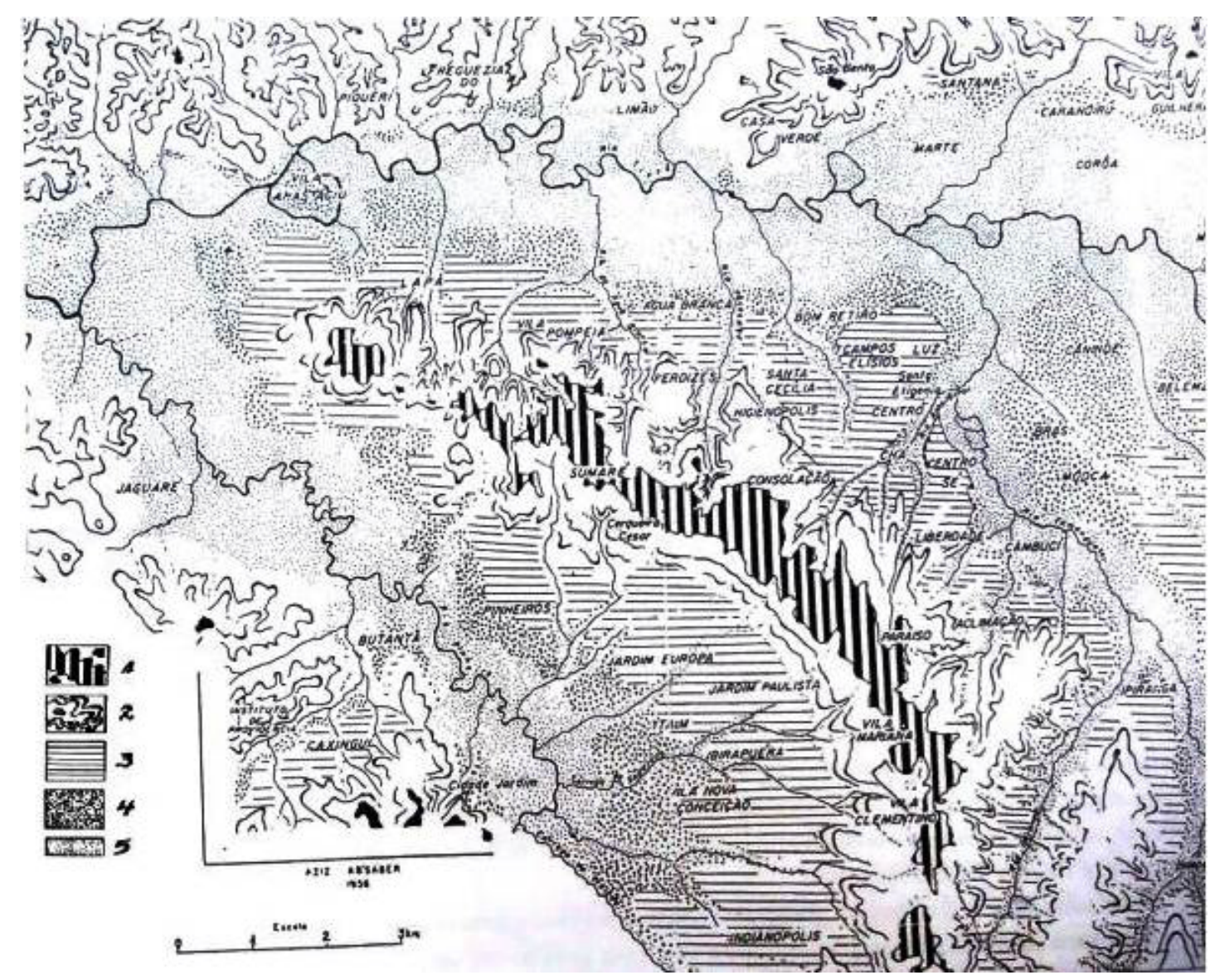

Figura 1 - Mapa Geomorfológico esquemático do sítio urbano de São Paulo. Fonte: Ab'Sáber,1957. Legenda: 1-Espigão Central (800-820m); 2-Altas colinas e espigões secundários (750-795m); 3-Terraços fluviais do nível intermediário (745-750m); 4-Baixos terraços fluviais dos vales do Pinheiros, Tietê e seus afluentes principais (725-730m); 5-Planícies dos aluviais do Tietê-Pinheiros e seus afluentes (720-722m).

8 Devido ao fato de muitos desses processos desencadearem benefícios diretos ou indiretos para os seres humanos surgiu a noção de serviços ambientais ou ecossistêmicos. A manutenção dos processos naturais e dos serviços associados, mesmo em ambiente urbano, é entendida como fundamental para que a sociedade mantenha certa estabilidade de sua base biofísica, evitando assim (ou ao menos minizando) problemas de fundo ambiental. 
A análise do autor aponta ações para manter tais processos e quando for o caso, manejar sua ocorrência com vistas a evitar a exacerbação de dinâmicas naturais que são incompatíveis com a ocupação humana consolidada, como deslizamentos, por exemplo.Os quatro compartimentos de relevo são:

\section{Áreas tabulares e relativamente planas favoráveis à ocupação urbana}

Supercompartimento ambiental estruturante da paisagem formado pelos baixos terraços dos rios Tietê, Pinheiros e afluentes principais, Espigão Central, altas colinas e patamares e rampas dos espigões secundários. Enorme área livre de inundações, favorável à ocupação e onde os processos de infiltração predominam sobre o escoamento superficial.

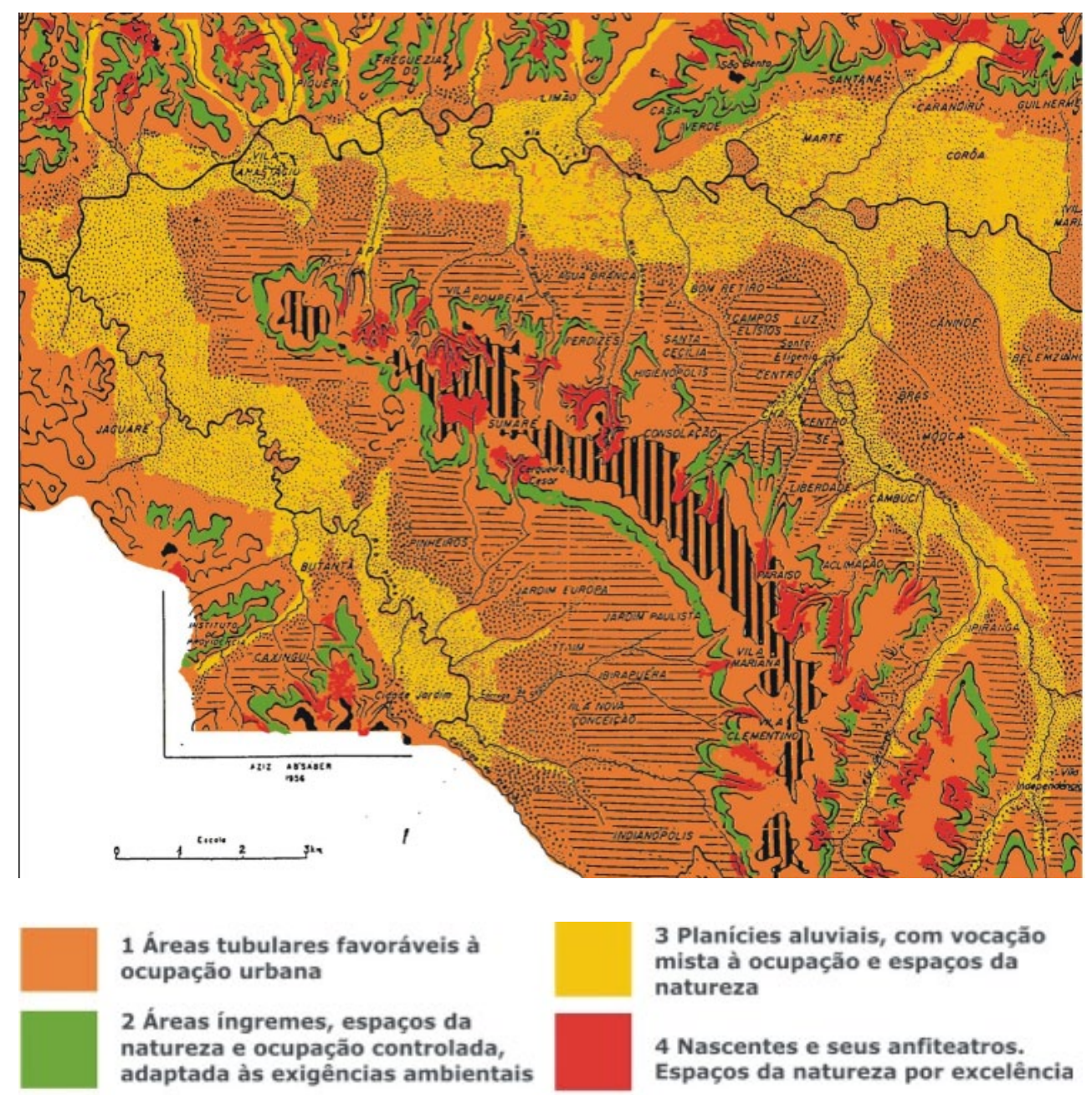

Figura 2 Esboço de compartimentação do relevo do sítio urbano de São Paulo. Fonte: Massafumi; Parma; Schutzer, 2005 apud Schutzer, 2012a. 
Schutzer $(2004,2012 a)$ recomenda o fomento da permeabilidade para que se garanta a qualidade dos processos naturais de infiltração, percolação e filtragem das águas pluviais. Esses processos são responsáveis pelo reabastecimento do lençol freático e das nascentes, retardando ainda a chegada da água da chuva aos canais de drenagem.

Outra medida importante é o controle do escoamento superficial, processo que como se sabe é incentivado pela impermeabilização do solo. Além da manutenção da permeabilidade, recomenda a instalação de reservatórios de detenção de águas pluviais`. $\mathrm{O}$ autor sugere o sombreamento do solo e o cuidado com a escolha dos materiais construtivos como forma de controlar a emissividade de calor. Quanto ao clima, predominam temperaturas mais amenas nas imediações do Espigão Central, enquanto que próximo à várzea do rio Tietê, verifica-se a tendência a um aquecimento diurno mais pronunciado, conforme explicam Tarifa e Armani (2001, p. 40).

\section{Áreas íngremes de vertentes das altas colinas}

Dada a declividade acentuada, neste compartimento predomina o processo de escoamento superficial sobre a infiltração. A combinação da declividade com índices pluviométricos significativos potencializa os deslizamentos.

Idealmente deveria ser mantida em estado natural ou densamente arborizada. Esse compartimento pode abrigar praças e parques, desde que feito terraceamento para controlar o escoamento superficial e tornar a topografia acessível às pessoas. Quando ocupadas, Schutzer recomenda o combate ao parcelamento do solo. A impermeabilização intensa associada a técnicas de contenção do escoamento superficial como a construção de reservatórios de retenção temporária ${ }^{10}$ também é uma medida útil (2004, p. 108). A topografia elevada garante boa ventilação e microclima mais ameno.

\footnotetext{
${ }^{9}$ Reservatórios de detenção, popularmente conhecidos como "piscinões", embora possam funcionar em termos hidrológicos apresentam problemas relacionados à poluição das águas, ao aspecto visual e rejeição da população. $O$ artigo apresentará adiante uma série de tipologias paisagísticas que sinalizam com alternativas mais naturalizadas, podendo essas sim, compor uma Infraestrutura Verde, substituindo com vantagens os reservatórios convencionais.

${ }^{10}$ A diferença entre reservatório de detenção e de retenção é que o primeiro pressupõe a liberação da água acumulada e por isso também é chamado de retenção temporária.
} 


\section{Nascentes}

As nascentes surgem em amplitude altimétrica de 750 a 795 metros, relativa, portanto, ao compartimento topográfico "altas colinas". Devido à redução de altitude, a temperatura sofre um ligeiro aumento.

Segundo Schutzer (2004, p.108-109), anfiteatros de drenagem são espaços da natureza por excelência e não deveriam ser ocupados, podendo, no entanto, ser aproveitados como parques e áreas de lazer. Se ocupados, deve ser dada atenção ao controle do escoamento superficial, processo natural predominante neste compartimento e que desencadeia erosão, deslizamento e assoreamento dos canais de drenagem. Neste sentido, recomenda-se o uso de reservatórios de retenção de águas pluviais.

A manutenção de sua umidade intrínseca está diretamente ligada à permeabilidade dos espigões e altas colinas. Deve ter densa arborização para estimular a infiltração, a percolação, a evaporação e evapotranspiração.

\section{Planícies aluviais ou várzeas}

São áreas baixas e planas, com solos permanentemente úmidos e que recebem água e sedimentos dos demais compartimentos. Nesta zona predomina o armazenamento de água sobre os processos de infiltração (muito limitada devido à proximidade do lençol freático) e de escoamento superficial (praticamente limitado ao escoamento concentrado nos corpos d'água).

O excesso de água tende a se acumular na superfície. Schutzer (2004) define as várzeas como espaços da natureza por excelência (p.109). Podem abrigar parques com vegetação densa, lagos e espaços institucionais de múltiplo uso.

Aocupação é possível em trechos amplos, contanto que nos compartimentos à montante exista boa permeabilidade do solo. É um compartimento ambiental receptor de processos naturais, e por isso seu manejo está vinculado à capacidade dos compartimentos indutores lidarem com o escoamento superficial. Presta-se ao represamento artificial, de detenção e de retenção.

A seguir, faremos uma investigação das tipologias paisagísticas usualmente asso- 
ciadas à Infraestrutura Verde, no sentido de detectar quais os processos naturais presentes e predominantes em cada uma delas. Este procedimento permitirá saber quais tipologias paisagísticas são mais indicadas para cada zona ambiental. Do ponto de vista da Infraestrutura Verde o método orienta a sua aplicação e do ponto de vista do zoneamento ambiental é uma extensão teórica, uma espécie de "plugin", em que novas possibilidades de intervenção na paisagem, já devidamente esmiuçadas em esquemas construtivos facilmente replicáveis, são colocadas à sua disposição.

\section{REVISANDO AS TIPOLOGIAS PAISAGÍSTICAS}

Um aspecto da Infraestrutura Verde que parece explicar a sua crescente popularidade entre os interventores da paisagem, seja no âmbito do projeto ou no do planejamento, diz respeito ao papel importante desempenhado por suas tipologias. Estes esquemas construtivos simples e muito didáticos são facilmente entendidos por arquitetos, engenheiros e até por leigos.

Essas tipologias também ganharam notoriedade porque algumas delas são cada vez mais requisitadas para compor planos de manejo de águas pluviais, muito embora entendemos que deveriam ser apreciadas em um contexto mais abrangente, abarcando todas as águas urbanas e não somente a água da chuva. As tipologias podem colaborar com objetivos outros que a drenagem urbana, integrando intervenções para o tratamento de efluentes, a proteção à biodiversidade e o conforto ambiental, por exemplo.

A introdução de tipologias em áreas urbanizadas colabora com a "criação de paisagens urbanas que mimetizam funções ecológicas e hidrológicas dos ambientes naturais" (CORMIER; PELLEGRINO, 2008, p. 127), promovendo serviços ambientais relacionados à drenagem, mobilidade, conforto ambiental, limpeza da água e do ar, biodiversidade, lazer e imagem local, entre outros. São intervenções mais vegetadas do que construídas e que enriquecem a comunidade e a paisagem local, cujo desempenho aumenta com o tempo.

A seguir, pretende-se descobrir que tipologias são mais indicadas para serem aplicadas em cada compartimento de relevo. Como vimos anteriormente, planícies fluviais, colinas, terraços e espigões também apresentam processos naturais predominantes, que se diferenciam entre si. $\mathrm{O}$ aproveitamento e o manejo desses processos permitem que se mantenha certa estabilidade da base biofísica da cidade, o que traz bene- 
fícios para a sociedade (água limpa, ar puro, clima agradável e a própria paisagem, por exemplo) e a poupa de uma série de problemas, como inundações, ilhas de calor, poluição atmosférica, baixa umidade do ar e deslizamentos de terra.

\section{Jardim de chuva}

Trata-se de um jardim rebaixado que recebe as águas do escoamento superficial das áreas próximas a fim de infiltrá-las. Por serem vegetados, colaboram com a limpeza da poluição difusa que é carreada pela água da chuva e também com o aumento da umidade do ar através da evapotranspiração associada ao metabolismo vegetal. Idealmente, devem possuir mecanismos de extravasamento para lidar com precipitações mais intensas ou prolongadas.

Quando associadas ao sistema viário, conferem sinuosidade ao leito carroçável, obrigando os veículos a diminuir sua velocidade. Neste sentido, jardins de chuva podem ser estruturas híbridas de traffic calming e microdrenagem que revertem a supremacia do automóvel, ajudando a resgatar a importância e a funcionalidade de ruas e calçadas.
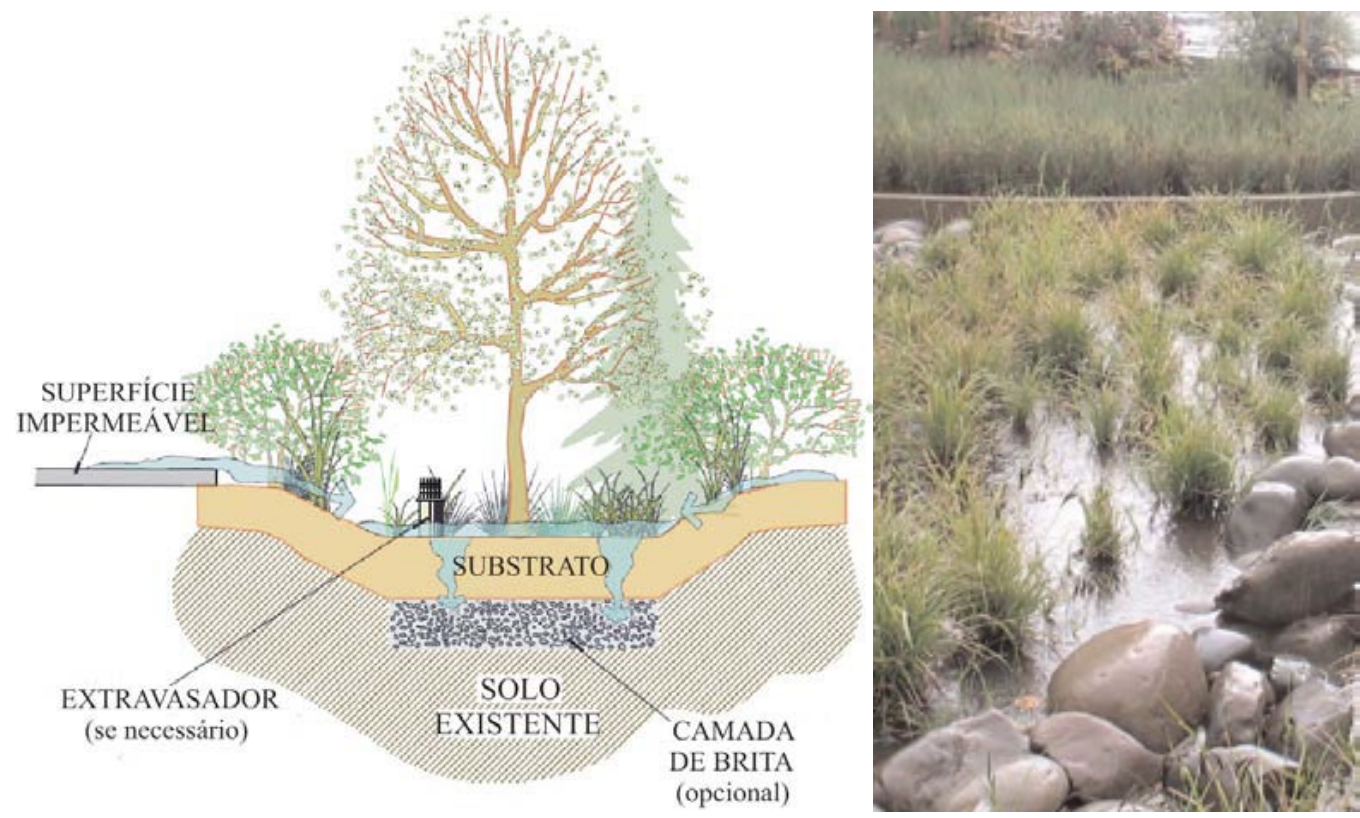

Figura 3 - Diagrama esquemático de jardim de chuva.

Adaptado de <http://www.portlandoregon.gov/bes/article/127474>. Acesso em 27/04/2015.

Locais de implantação: Nos compartimentos ambientais em que predominam os processos de infiltração: as "áreas tabulares". 


\section{Canteiro pluvial}

Basicamente jardins de chuva de menor tamanho (Idem, p. 130), os canteiros pluviais podem dispensar a infiltração, executando apenas a evaporação e a evapotranspiração do escoamento superficial armazenado.Tipologia adaptável para cumprir funções de traffic calming.
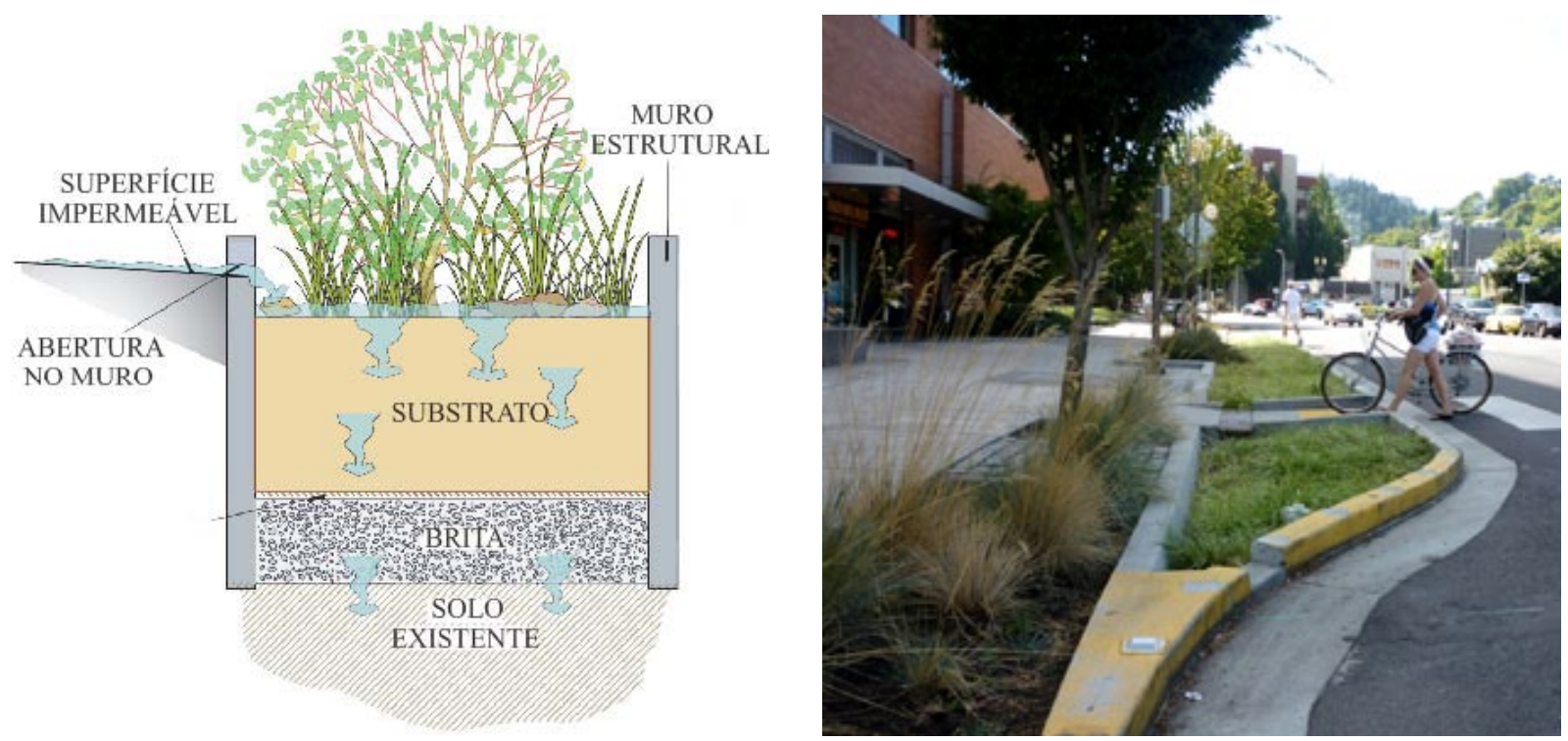

Figura 4 - Diagrama esquemático de canteiro pluvial de infiltração.

Adaptado de <http://www.portlandoregon.gov/bes/article/127476> e

$<$ http://theintertwine.org/adventures/storming-downtown-portland>. Acesso em 02/07/2015.

Locais de implantação: Canteiros pluviais de infiltração se prestam à alocação nas "áreas tabulares". Em sua versão sem infiltração, a tipologia pode ser aplicada nas "planícies aluviais", compartimento em que o armazenamento é o processo natural predominante. E também em "nascentes "e nas "áreas íngremes das vertentes das altas colinas", setores em que o escoamento superficial deve ser manejado com vistas a evitar processos erosivos, deslizamentos e assoreamento das galerias pluviais.

\section{Biovaleta}

São faixas lineares rebaixadas e dotadas de vegetação que realizam o escoamento da água da chuva, podendo conectar diferentes tipologias paisagísticas, espaços públicos e sistemas convencionais de drenagem.

Apresentam alguma capacidade de infiltrar a água do solo, realizando também a lim- 
peza da poluição difusa carreada pelo escoamento superficial, desacelerando o escoamento das superfícies impermeabilizadas adjacentes.

Outros benefícios da tipologia dizem respeito à captura e sedimentação de material que de outra maneira iria parar nos canais fluviais, comprometendo a qualidade da água, ou, no caso de ambientes densamente urbanizados, diminuindo a capacidade hidráulica das galerias de águas pluviais.

Potencialmente, as biovaletas colaboram com o aumento da umidade do ar por meio da evapotranspiração promovida por sua vegetação.
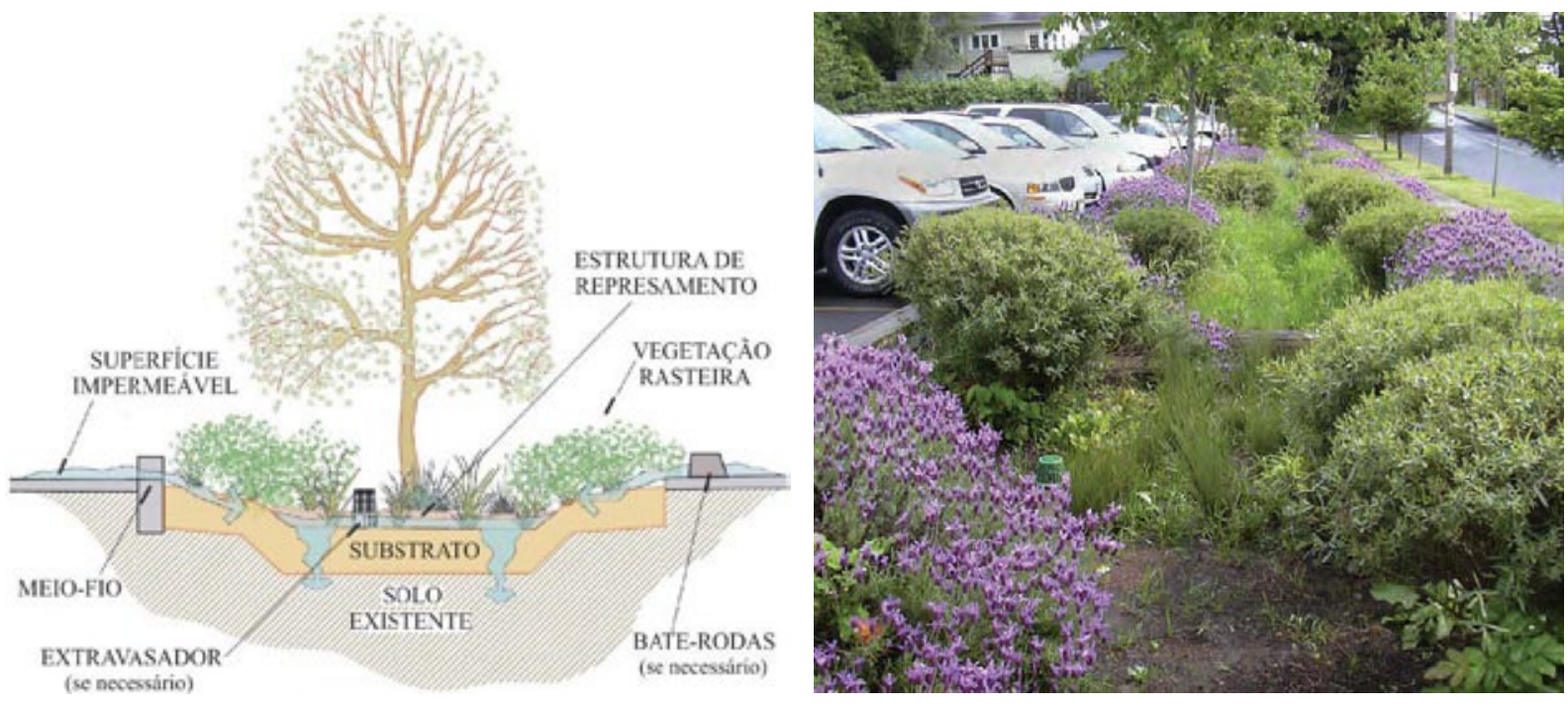

Figura 5 - Diagrama esquemático de biovaleta.

Adaptado de < http://www.portlandoregon.gov/bes/article/127473>. Acesso em 27/04/2015.

Locais de implantação: A sua aplicação pode acontecer em toda a bacia hidrográfica, embora seja nas "áreas tabulares" que a tipologia vá apresentar seu maior desempenho, dada a facilidade de infiltração desse compartimento ambiental.

\section{Lagoa pluvial}

No contexto da Infraestrutura Verde, lagoas são tipologias que desempenham funções importantes, relacionadas ao armazenamento do excesso da água da chuva e ao extravasamento dos canais fluviais; ao aumento da umidade do ar por meio da evaporação de sua lâmina d'água; e da limpeza da poluição difusa carreada pelo escoamento superficial, sobretudo pela ação do sol. 
Essa tipologia cria importantíssimos habitats para a fauna e invariavelmente transforma suas imediações nas principais áreas de lazer e de recreação pública. Cormier e Pellegrino (2008) destacam que a tipologia, devido às dimensões e à capacidade de armazenar grandes volumes de água.

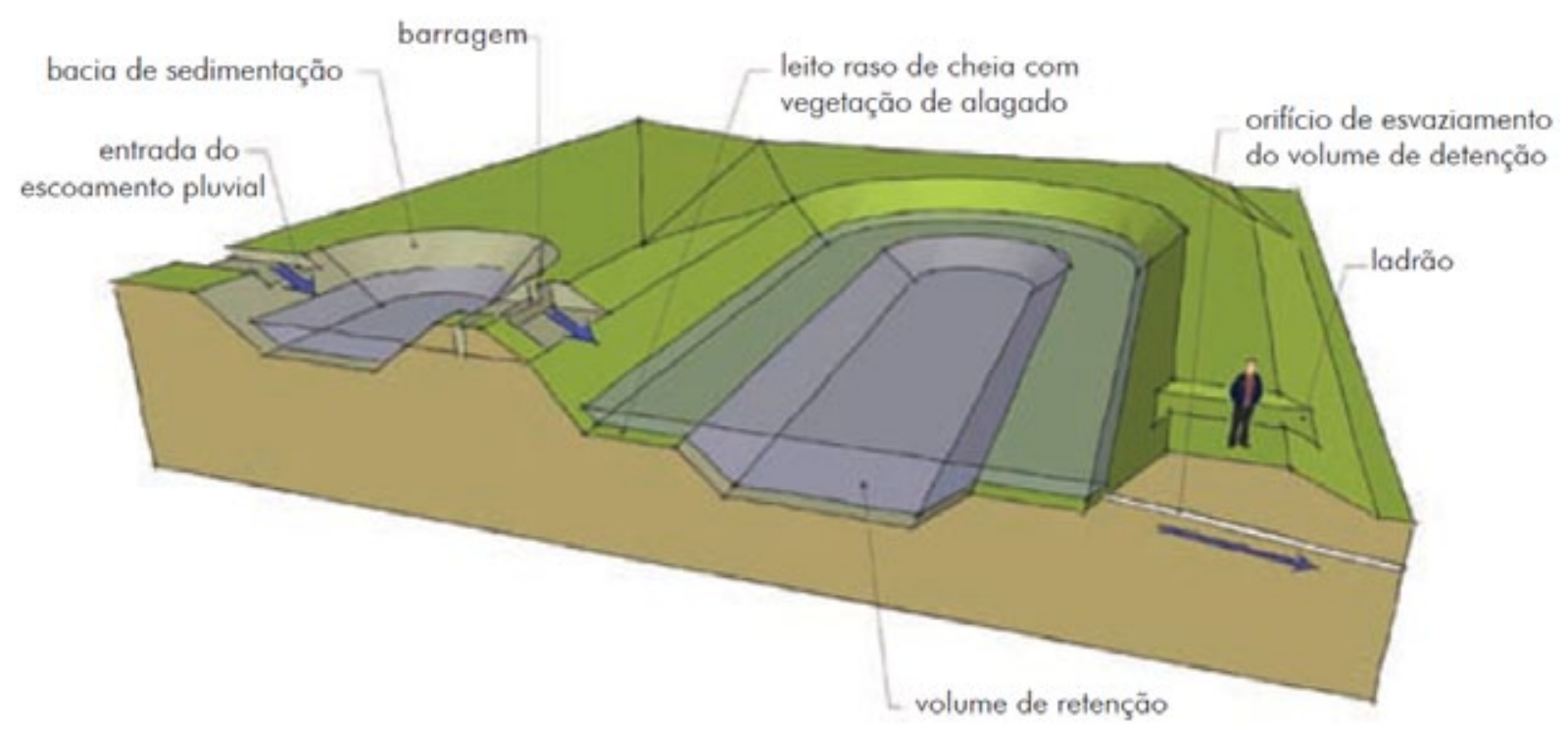

Figura 6 - Esquema de uma lagoa pluvial. Fonte: CORMIER; PELLEGRINO, 2008, p 134.

Locais de implantação: As lagoas pluviais são indicadas para as "várzeas", compartimento ambiental em que o processo de armazenamento de água é o predominante. Também podem trazer benefícios para setores em que o escoamento superficial deve ser controlado: "nascentes" e "áreas íngremes das vertentes das altas colinas", neste caso desde de que cuidadosamente impermeabilizada.

\section{Alagado construído}

Diferencia-se da lagoa pluvial por ter vegetação mais expressiva e variada. É mais associado à recepção e tratamento de efluentes do que propriamente à capacidade de armazenar o excedente da água da chuva e o extravasamento dos canais fluviais. Seu solo dá suporte para vegetação e funciona como "camada filtrante que possibilita ações de sorção e a atividade microbiológica que mineraliza a matéria orgânica ainda contida no efluente, disponibilizando os minerais e nutrientes para a vegetação" (ZANELLA, 2008, p. 24)

A variação no nível da água contribui para a ciclagem de nutrientes. Determinadas combinações entre solo, planta, água e o sentido de seu fluxo estabelecem funções 
específicas, como por exemplo, decomposição de matéria orgânica, erradicação de patógenos e oxidação de metais pesados. Alagados construídos aumentam a umidade do ar e criam importantes habitats, possuindo grande potencial paisagístico. Podem ser projetados para mimetizar áreas de várzeas, armazenando o escoamento superficial e limpando a poluição difusa que este carrega em áreas densamente urbanizadas. Segundo France, alagados

funcionam como esponjas gigantes que diminuem a velocidade e absorvem o excesso de escoamento de águas pluviais, liberando gradualmente a água armazenada durante um período prolongado. Isso reduz a vazão de pico à jusante, diminuindo a probabilidade de inundações (2003, p. 18. Tradução nossa).

Locais de implantação: Recomendada para as "várzeas", onde predomina o armazenamento de água. Também é indicada para setores em que o escoamento superficial deve ser controlado ("nascentes" e "áreas íngremes das vertentes das altas colinas") e pontualmente em qualquer parte que necessite realizar o tratamento de águas residuais, embora nestes casos possa requerer consideráveis obras civis.

\section{Cisterna}

Estrutura ancestral para captar e armazenar a água da chuva. No contexto da Infraestrutura Verde, essa tipologia colabora com a redução do escoamento superficial. A água coletada pode ser utilizada para irrigar jardins e hortas comunitárias e em qualquer atividade que não exija que a água seja potável. Na literatura consultada, aparecem adaptações chamadas de rain barrel. As cisternas sinalizam como estratégia descentralizada e complementar de abastecimento de água.

Locais de implantação: Do ponto de vista da preservação de certa integridade dos processos naturais, sua aplicação é indicada para os compartimentos ambientais em que se faz necessário controlar o escoamento superficial: "nascentes" e "áreas íngremes das vertentes das altas colinas". No entanto, tendo em vista o abastecimento de água e as altas taxas de impermeabilização das bacia hidrográficasdensamente urbanizadas, é útil em todos os compartimentos ambientais. 

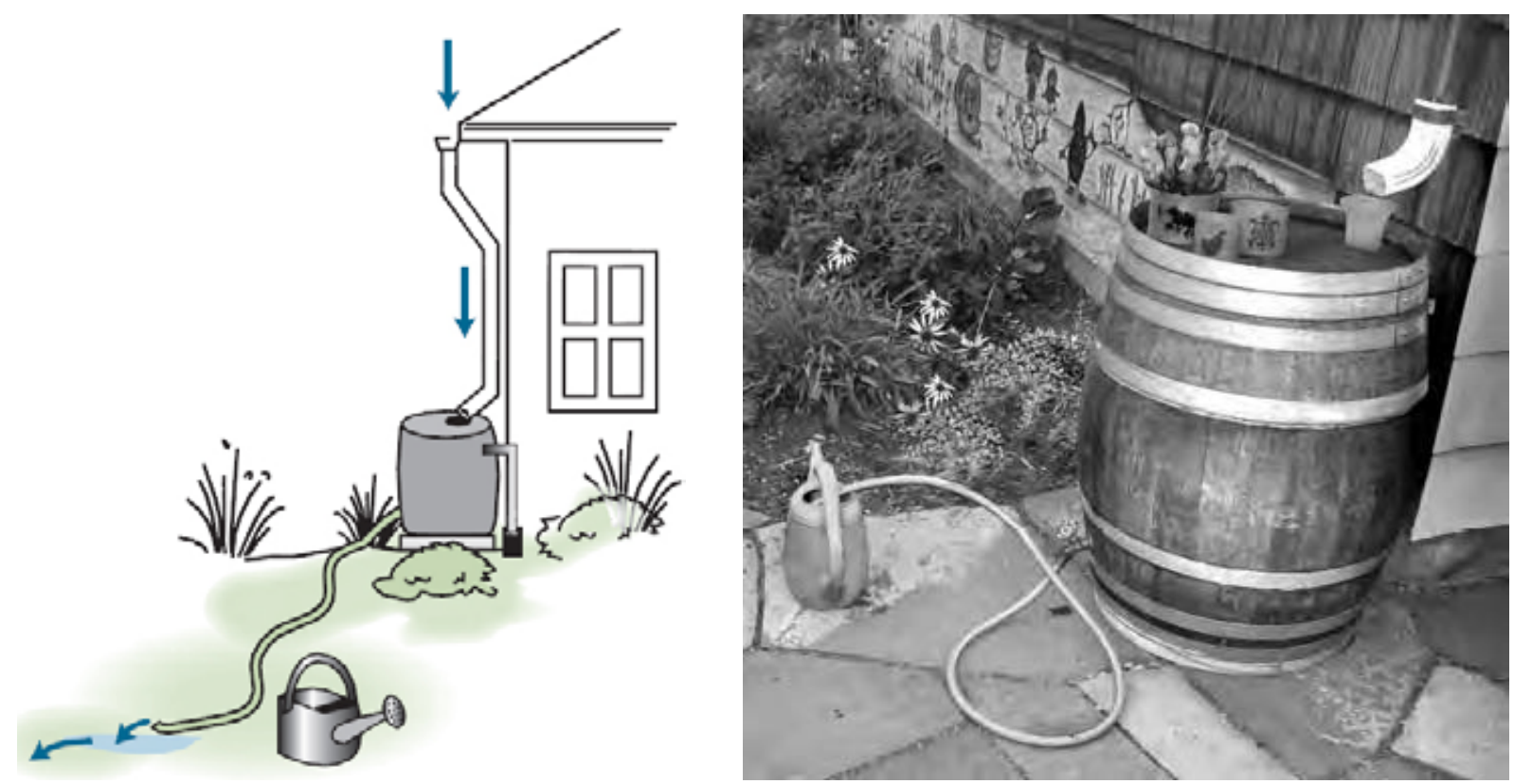

Figura 7 - Diagrama esquemático de cisterna.

Fonte: < http://www.portlandoregon.gov/bes/article/378190>. Acesso em 27/04/2015.

\section{Teto verde}

O uso de vegetação encima de lajes e telhados apresenta muitas formas, indo desde plantas suculentas assentadas sobre fina camada de substrato acondicionado em estruturas modulares até verdadeiros jardins suspensos com hortas e árvores frutíferas. Por isso tetos verdes são classificados em extensivos (leves, com seção de substrato entre 5 e $15 \mathrm{~cm}$ ) e intensivos (entre 20 e 60cm). Como relatam Cormier e Pellegrino (2008, p. 135), a tipologia absorve água da chuva, reduz o efeito da ilha de calor, contribui para a eficiência energética das edificações, cria habitats para a fauna e até estendem a vida útil da impermeabilização de suas lajes. Tetos verdes intensivos possuem capacidade de infiltrar água da chuva em seu substrato, aumentando a umidade do ar por meio da evapotranspiração de sua cobertura vegetal. A variante extensiva é mais modesta em relação a essas funções, mas retarda o escoamento superficial.

Locais de implantação: Tendo em vista que seus benefícios sociais extrapolam a manutenção da estabilidade dos processos naturais da bacia hidrográfica, recomenda-se aplicação de tetos verdes em todos os compartimentos ambientais. 


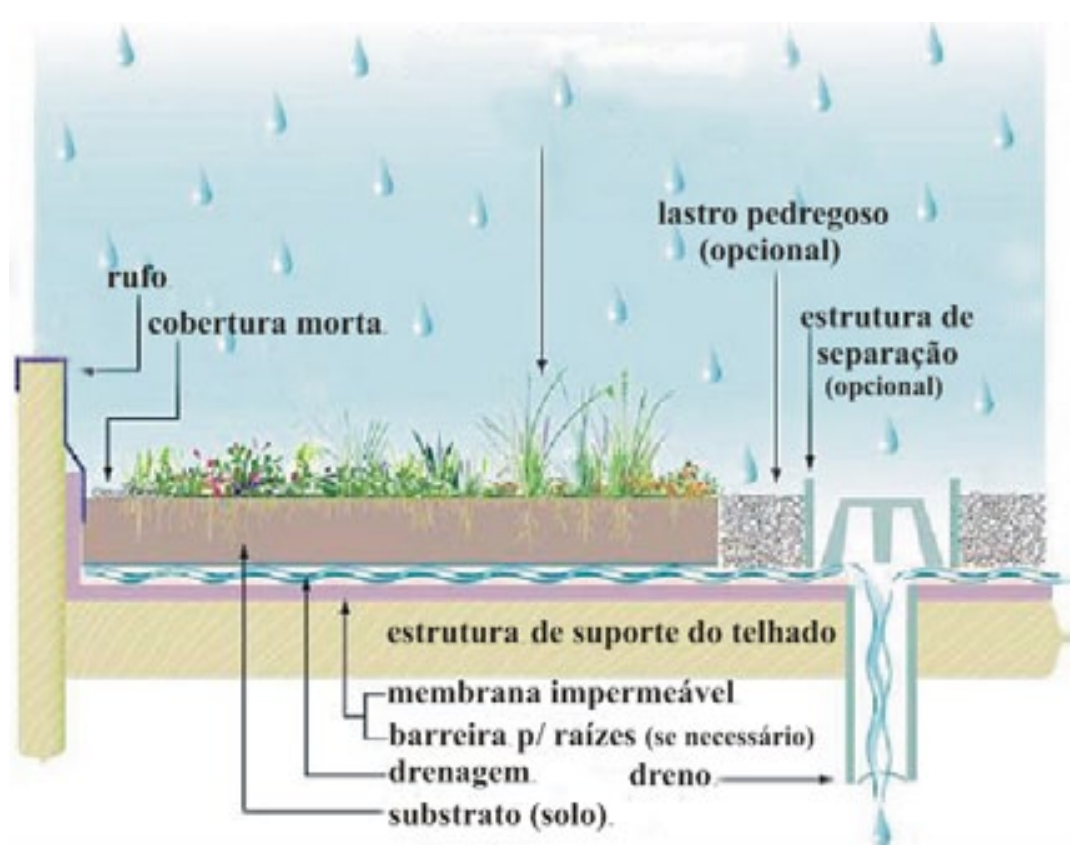

Figura 8 - Diagrama esquemático de teto verde.

Adaptado de <www.portlandonline.com/shared/cfm/image.cfm?id=78405>.Acesso em 27/04/2015.

\section{Pavimento drenante (ou permeável)}

Corresponde ao conjunto de superfícies construídas que permitem a infiltração da água no solo, seja por sua porosidade (asfalto ou concreto poroso), seja por meio dos interstícios entre suas unidades constituintes (blocos intertravados, paralelepípedos, blocos vazados, brita e pedriscos). Observa-se que a aplicação de pisos drenantes não tem levado em conta as características locais de drenagem. Tem sido aplicado em áreas em que naturalmente o solo possui pouquíssima capacidade de infiltração (várzeas, por exemplo).

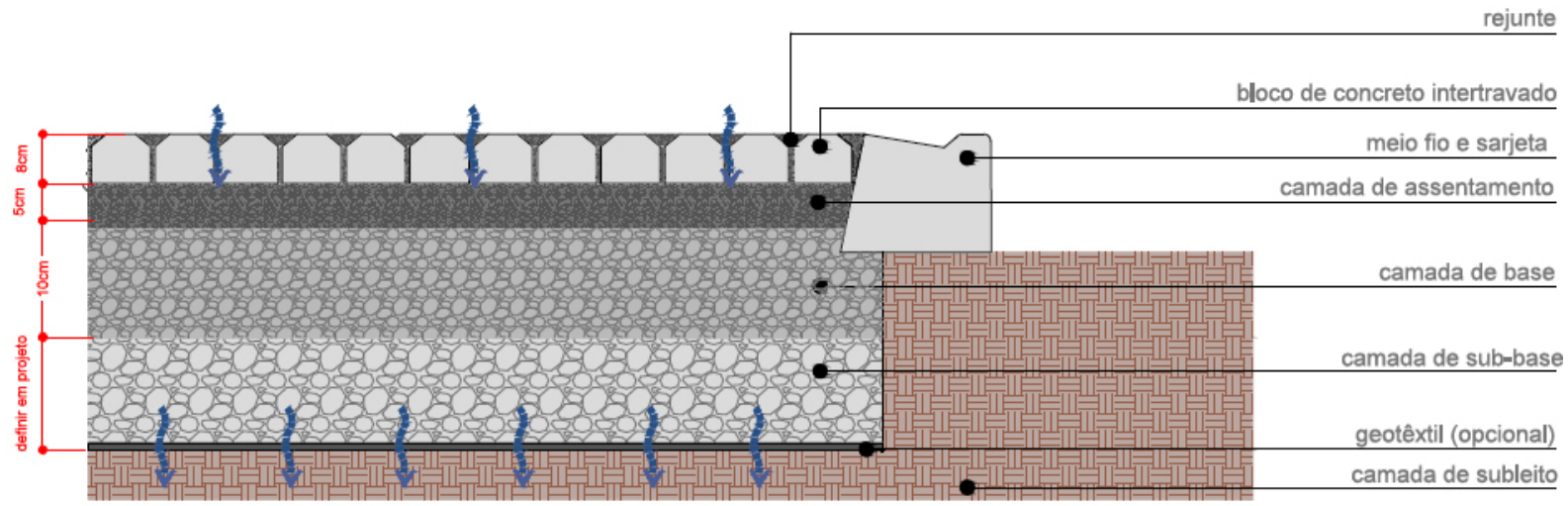

Figura 9 - Esquema de pavimento intetravado.

Fonte: <http://solucoesparacidades.com.br/saneamento/pavimento-permeavel/>. Acesso em 06/06/2014. 


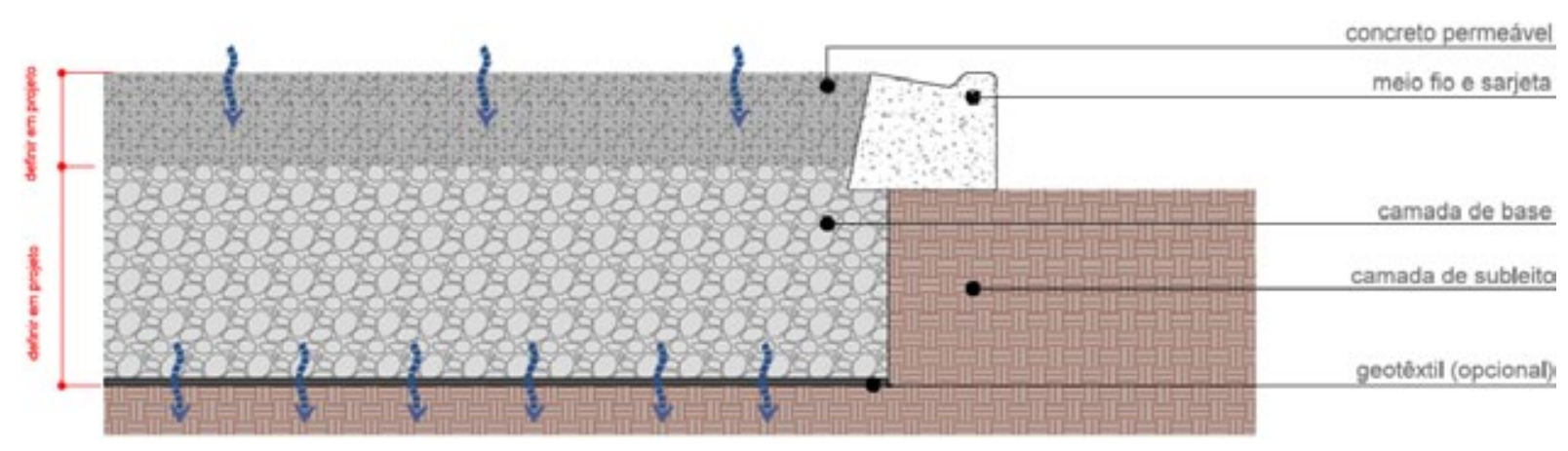

Figura 10 - Esquema de pavimento permeável.

Fonte: <http://solucoesparacidades.com.br/saneamento/pavimento-permeavel/>. Acesso em 27/04/2015.

Locais de implantação: Os compartimentos ambientais em que faz mais sentido aplicar pisos drenantes são aqueles em que os processos naturais de infiltração são os predominantes, isto é, as "áreas tabulares".

\section{Córrego renaturalizado (ou reabilitado)}

Pinkham afirma que a expressão mais radical da Infraestrutura Verde é a reabilitação de córregos enterrados em galerias (1999, p. 12). O chamado "daylighting" traz muitos benefícios: a qualidade da água melhora devido à exposição ao ar, sol e vegetação; inundações minimizam com o aumento da capacidade hidráulica do canal; surgem habitats para fauna e áreas de interesse para a população (1999, 2000). Pinkham observa é comum que o destamponamento implique na construção de canais, o que coloca a oportunidade de projetar o novo leito de maneira sinuosa e com revestimento rugoso. São diretrizes que desaceleram a velocidade das águas, minimizando a incidência de inundações. Outra estratégia é o escalonamento do leito, em que a queda entre patamares dissipa a energia hidráulica e a velocidade das águas. Por fim, ao invés da antiga galeria ser demolida, pode funcionar sistema de apoio que recebe o extravasamento do novo canal durante precipitações extremas. Acompanhada da criação de um parque linear, o "daylighting" reabilita alguns dos processos naturais e funções ecossistêmicas de sua planície de inundação natural (várzea). O córrego "desocultado" também contribui com a recarga de aquíferos e com a manutenção de uma vigorosa vegetação lindeira beneficiada com a significativa umidade do solo. 


\begin{tabular}{|c|c|c|}
\hline $\begin{array}{l}\text { TIPOLOGIA } \\
\text { PAISAGÍSTICA }\end{array}$ & $\begin{array}{l}\text { PROCESSO NATURAL } \\
\text { INCENTIVADO OU MIMETIZADO }\end{array}$ & $\begin{array}{c}\text { PRINCIPAIS SERVIÇOS } \\
\text { ECOSSISTÊMICOS } \\
\text { DESEMPENHADOS }\end{array}$ \\
\hline JARDIM DE CHUVA & $\begin{array}{l}\text {-infiltração } \\
\text {-recarga dos aquíferos } \\
\text {-evapotranspiração } \\
\text {-filtragem da água } \\
\text {-filtragem do ar }\end{array}$ & $\begin{array}{l}\text {-manejo do escoamento superficial } \\
\text {-aumento da umidade do ar } \\
\text {-criação de habitats } \\
\text {-limpeza da poluição difusa } \\
\text {-melhora na qualidade do ar } \\
\text {-aumento da umidade do solo adjacente }\end{array}$ \\
\hline CANTEIRO PLUVIAL & $\begin{array}{l}\text {-infiltração ou armazenamento } \\
\text {-evapotranspiração } \\
\text {-filtragem da água } \\
\text {-filtragem do ar } \\
\text {-evaporação (somente para versão de } \\
\text { armazenamento) } \\
\text {-recarga dos aquíferos } \\
\text { (na versão com infiltração) }\end{array}$ & $\begin{array}{l}\text {-manejo do escoamento superficial } \\
\text {-aumento da umidade do ar } \\
\text {-criação de habitats } \\
\text {-limpeza da poluição difusa } \\
\text {-melhora na qualidade do ar } \\
\text {-aumento da umidade do solo adjacente }\end{array}$ \\
\hline BIOVALETA & $\begin{array}{l}\text {-escoamento das águas } \\
\text {-infiltração } \\
\text {-filtragem das águas } \\
\text {-captura e sedimentação de material } \\
\text { carreado pelo escoamento superficial } \\
\text {-evapotranspiração }\end{array}$ & $\begin{array}{l}\text {-manejo do escoamento superficial } \\
\text {-limpeza da poluição difusa } \\
\text {-conservação das infraestruturas de } \\
\text { drenagem } \\
\text {-aumento da umidade do ar } \\
\text {-conexão de áreas verdes } \\
\text {-aumento da umidade do solo adjacente } \\
\text {-criação de habitats }\end{array}$ \\
\hline LAGOA PLUVIAL & $\begin{array}{l}\text {-armazenamento de água } \\
\text {-evaporação } \\
\text {-depuração da água captada } \\
\text {-recarga dos aquíferos }\end{array}$ & $\begin{array}{l}\text {-manejo do escoamento superficial } \\
\text {-aumento da umidade do ar } \\
\text {-criação de habitas } \\
\text {-limpeza da poluição difusa }\end{array}$ \\
\hline $\begin{array}{l}\text { ALAGADO } \\
\text { CONSTRUÍDO }\end{array}$ & $\begin{array}{l}\text {-armazenamento de água } \\
\text {-evaporação } \\
\text {-evapotranspiração } \\
\text {-filtragem da água } \\
\text {-ciclagem de nutrientes } \\
\text {-filtragem do ar } \\
\text {-recarga dos aquíferos (às vezes) }\end{array}$ & $\begin{array}{l}\text {-manejo do escoamento superficial } \\
\text {-aumento da umidade do ar } \\
\text {-limpeza da poluição difusa } \\
\text {-tratamento de efluentes (depende) } \\
\text {-melhora na qualidade do ar } \\
\text {-criação de habitats } \\
\text {-fornecimento de água de reuso } \\
\text { (depende) }\end{array}$ \\
\hline CISTERNA & -armazenamento de água & $\begin{array}{l}\text {-manejo do escoamento superficial } \\
\text {-fornecimento de água semi-potável }\end{array}$ \\
\hline
\end{tabular}




\begin{tabular}{|c|c|c|}
\hline TETO VERDE & $\begin{array}{l}\text {-infiltração } \\
\text {-evapotranspiração } \\
\text {-filtragem do ar }\end{array}$ & $\begin{array}{l}\text {-manejo do escoamento superficial } \\
\text {-aumento da umidade do ar } \\
\text {-melhora na qualidade do ar } \\
\text {-aumento eficiência energética dos } \\
\text { edifícios } \\
\text {-aumento da vida útil da } \\
\text { impermeabilização } \\
\text {-criação de habitats }\end{array}$ \\
\hline $\begin{array}{l}\text { PAVIMENTO } \\
\text { DRENANTE }\end{array}$ & $\begin{array}{l}\text {-infiltração } \\
\text {-recarga dos aquíferos (na versão } \\
\text { infiltração) }\end{array}$ & $\begin{array}{l}\text {-manejo do escoamento superficial } \\
\text {-aumento da umidade do solo adjacente }\end{array}$ \\
\hline $\begin{array}{c}\text { CÓRREGO } \\
\text { RENATURALIZADO }\end{array}$ & $\begin{array}{l}\text {-recepção do escoamento superficial de } \\
\text { águas pluviais } \\
\text {-escoamento das águas fluviais } \\
\text {-comunicação com aquífero } \\
\text {-limpeza das águas } \\
\text {-evaporação } \\
\text {-evapotranspiração }\end{array}$ & $\begin{array}{l}\text {-manejo do escoamento superficial } \\
\text {-aumento da condutividade hidráulica } \\
\text { do canal } \\
\text {-melhora na qualidade da água } \\
\text { do córrego } \\
\text {-aumento da umidade do ar } \\
\text {-aumento da umidade do solo adjacente } \\
\text {-criação de habitats } \\
\text {-conexão de áreas verdes }\end{array}$ \\
\hline PARQUE LINEAR & $\begin{array}{l}\text {-armazenamento } \\
\text {-evaporação } \\
\text {-evapotranspiração } \\
\text {-filtragem da água } \\
\text {-filtragem do ar } \\
\text {-recarga dos aquíferos }\end{array}$ & $\begin{array}{l}\text {-manejo do escoamento superficial e do } \\
\text { extravasamento do canal fluvial } \\
\text {-aumento da umidade do ar } \\
\text {-limpeza da poluição difusa } \\
\text {-melhora na qualidade do ar } \\
\text {-criação de habitats }\end{array}$ \\
\hline $\begin{array}{l}\text { COBERTURA } \\
\text { ARBÓREA }\end{array}$ & $\begin{array}{l}\text {-evapotranspiração } \\
\text {-filtragem do ar } \\
\text {-infiltração } \\
\text {-amortecimento da chuva } \\
\text {-aeração do solo } \\
\text {-ciclagem de nutrientes }\end{array}$ & $\begin{array}{l}\text {-aumento da umidade do ar } \\
\text {-melhora da qualidade do ar } \\
\text {-manejo do escoamento superficial } \\
\text {-contenção de taludes } \\
\text {-controle de erosão } \\
\text {-conforto ambiental } \\
\text {-amenização de ruídos } \\
\text {-proteção do solo } \\
\text {-criação de habitats } \\
\text {-criação de solo } \\
\text {-sequestro de carbono }\end{array}$ \\
\hline
\end{tabular}

Tabela 01 - Síntese dos principais processos naturais e serviços ecossistêmicos de cada tipologia. Elaborado pelo autor. 


\section{Parque linear}

Parques lineares criam áreas seguras para receber o eventual extravasamento de córregos e cotidianamente oferecem ampla gama de serviços e possibilidades para a população: lazer, esporte, convívio, identidade local e contato com a natureza. Também aumentam a umidade do ar, combatendo as ilhas de calor.

Schjetnan;Calvillo;Peniche (1997, p. 55) apontam que espaços abertos lineares têm várias qualidades, entre elas: capacidade de organizar sistemas de locomoção de pedestres e bicicletas;estabelecimento de corredores de ventilação e microclimas com maior umidade do ar e oxigenação;proteção de elementos naturais de valor ecológico ou visual.

O programa "100 parques para São Paulo" reconhece o saneamento, o combate às inundações, a reurbanização e o lazer como funções dos parques lineares.

\section{Cobertura Arbórea}

Embora possa ser obtida com a aplicação das demais tipologias paisagísticas, vale registrar que sua presença é indicada para todos os compartimentos ambientais. No entanto, nas áreas de várzea e de nascentes sua aplicação possui maior desempenho devido à presença de umidade no solo, o que garante vigor e potencia para os processos naturais intrínsecos.

\section{SOBRE A APLICAÇÃO DAS TIPOLOGIAS PAISAGÍSTICAS EM ÁREAS DENSA- MENTE URBANIZADAS}

A identificação dos processos naturais associados a cada tipologia paisagística e o exercício subsequente de indicar qual tipologia é indicada para cada compartimento ambiental revelaram que a aplicação da Infraestrutura Verde tem dois vieses. Por um lado, sua aplicação incentiva processos naturais cuja manutenção é fundamental para que ocupação humana não antagonize com a conservação da natureza. O outro enfoque tem a ver com processos incompatíveis com a ocupação consolidada de áreas que não deveriam ter sido ocupadas, como várzeas. Dentre esses processos, o 
escoamento superficial desponta absoluto.

A Infraestrutura Verde passa a lidar, então, com processos naturais que são potencialmente prejudiciais para as cidades e para as pessoas, ganhando um caráter muito mais de manejo e de restauração ecológica do que de conservação ou preservação dos processos naturais e da biodiversidade existente.Os objetivos passam a ser a produção ou o incremento de serviços ambientais para combater mazelas da urbanização: poluição do ar e da água, inundações, perda de habitats, ilhas de calor e baixa umidade do ar, entre outros.

Identificamos que há tipologias paisagísticas cuja aplicação em determinada zona ambiental não se justifica muito fortemente quanto ao objetivo coletivo de manter certa estabilidade da base biofísica da cidade, mas que podem ser muito úteis para alcançar outros objetivos, que dizem respeito mais à esfera privada. Alagados construídos nas áreas tabulares, por exemplo, não fazem sentido do ponto de vista da compatibilização entre os processos naturais predominantes nesta zona ambiental (infiltração) e os desempenhados pela tipologia (armazenamento). No entanto, podem trazer benefícios no que diz respeito ao tratamento de efluentes do lote. Note-se que a aplicação neste caso demanda mais intervenções do que se fosse aplicada nos fundos de vale, cuja capacidade inerente de armazenamento dispensa obras de impermeabilização.Outras tipologias paisagísticas, no entanto, não deveriam ser aplicadas em determinadas zonas ambientais, seja porque facilitam processos que não são os predominantes na área ou porque sua aplicação facilita processos indesejados e até mesmo perigosos em áreas densamente urbanizadas (um jardim de chuva aplicado em áreas íngremes pode induzir deslizamentos de terra, por exemplo).

E por fim, tendo em vista as nossas conclusões sobre a aplicação de pavimentos drenantes, que contradizem fortemente a verificada aplicação universal dessa tipologia (mesmo em áreas que naturalmente são pouco permeáveis), registramos aqui a necessidade de novos estudos sobre a tipologia. A mais popular e aplicada das tipologias apresenta desempenho satisfatório em qualquer situação? Sua aplicação não deveria prever diferenciação das espessuras de camadas porosas do leito e do subleito, de acordo com as características de drenagem da área a ser aplicada?

A tabela a seguir, sintetiza essas informações. 


\begin{tabular}{|c|c|c|c|c|}
\hline \multirow[b]{2}{*}{ TIPOLOGIA } & \multicolumn{4}{|c|}{ ZONA AMBIENTAL } \\
\hline & $\begin{array}{c}\text { Áreas } \\
\text { tabulares }\end{array}$ & $\begin{array}{c}\text { Áreas } \\
\text { íngremes }\end{array}$ & Nascentes & Várzea \\
\hline Jardim de chuva & $x x$ & - & - & - \\
\hline Canteiro pluvial com infiltração & $x x$ & - & - & - \\
\hline Canteiro pluvial sem infiltração & - & $x$ & $x$ & $X X$ \\
\hline Biovaleta & $x X$ & $x$ & $x$ & $x$ \\
\hline Lagoa pluvial & - & $x$ & $x$ & $x X$ \\
\hline Alagado construído & $X^{(s+)}$ & $x$ & $x$ & $x X$ \\
\hline Cisterna & $X^{(s+)}$ & $x$ & $x$ & $x X$ \\
\hline Teto verde & $X^{(s+)}$ & $x$ & $x$ & $x$ \\
\hline Pavimento drenante & $x X$ & $X^{(+e)}$ & $X^{(+e)}$ & $X^{(+e)}$ \\
\hline Córrego reabilitado & - & - & $x x$ & $x x$ \\
\hline Parque linear & - & - & $x x$ & $x X$ \\
\hline Arborização urbana & $x$ & $x$ & $x x$ & $x x$ \\
\hline
\end{tabular}

Tabela 02 - Quadro síntese para aplicação das tipologias paisagísticas de acordo com zoneamento ambiental. Legenda:

XX máximo desempenho na aplicação da tipologia, com vistas ao incentivo de processos naturais predominantes na zona ambiental.

X aplicação compatível, mas com menor desempenho. Tipicamente, a tipologia maneja processos naturais predominantes que se mostram incompatíveis com a ocupação consolidada.

$\mathbf{X}^{\left(\mathbf{s}^{+}\right)}$aplicação socialmente positiva, mas que não diz respeito ao objetivo coletivo de manter certa estabilidade da base biofísica da cidade. Aplicação indicada para obtenção de serviços ambientais cuja apropriação é majoritariamente privada.

$\mathbf{X}^{(+e)}$ aplicação que demanda mais estudos para verificação de desempenho na zona ambiental indicada.

- aplicação incompatível. Tipologia facilita processos naturais que não são os predominantes na zona ambiental indicada. Desempenho baixo ou nulo, podendo desencadear impactos indesejados. 


\section{ESTUDO DE CASO}

A microbacia escolhida para estudo de caso é a do córrego Água Preta, um dos muitos córregos ocultos ${ }^{11}$ de São Paulo. Localizado na zona oeste da cidade, drena uma área de $4,12 \mathrm{~km}^{2}$ tendo sua foz junto ao Rio Tietê. É uma área com baixa vulnerabilidade social, alto índice de desenvolvimento humano e densamente urbanizada. A exemplo do que aconteceu com as cerca de outras duas dezenas de bacias hidrográficas que nascem no Caaguaçu e que abrigam as áreas mais densamente urbanizadas da capital paulista, a impermeabilização maciça, a supressão radical da cobertura vegetal e a substituição das linhas naturais de drenagem por galerias subterrâneas alterou sobremaneira a hidrologia. Segundo estudo de Menegasse-Velásquez (1996), a antropização da bacia reduziu em $75 \%$ a infiltração (p. 112) e aumentou o escoamento superficial em $121 \%$ (p.91).
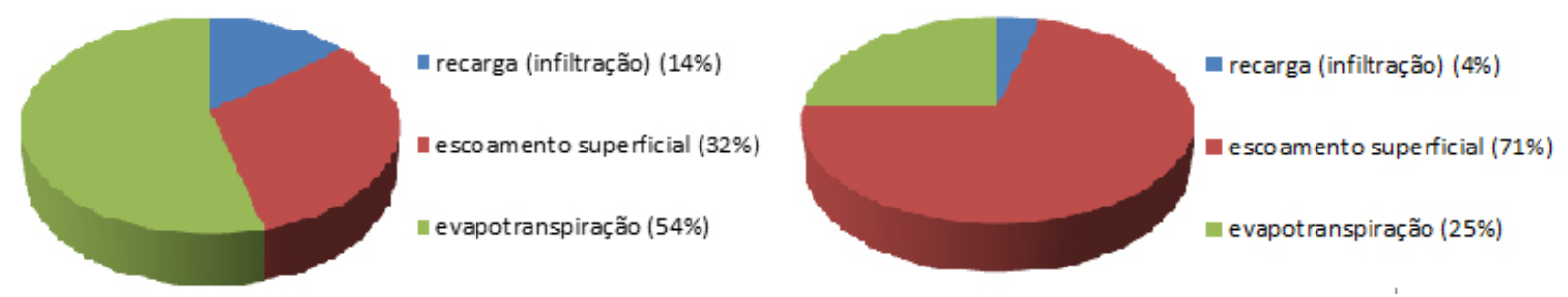

Figura 11 - Balanços hídricos pré-ocupação da bacia (esquerda) e urbanizada (direita). (Valores em relação à precipitação anual). Adaptado de Menegasse-Velásquez (1996).

Também diminuiu sensivelmente a capacidade que a paisagem tem de evaporar, evapotranspirar e interceptar as precipitações pluviométricas. $O$ resultado é que a rápida concentração da água da chuva sob forma de escoamento superficial faz a bacia hidrográfica apresentar picos de vazão maiores e mais rápidos do que em condições naturais, recessão brusca das vazões e tendência à ocorrência de enchentes secundárias (TUCCl,2006, p. 402). A erradicação da água na paisagem do Água Preta também explica a aridez climática que torna a região em que está inserida (Lapa), uma das áreas mais quentes da cidade (TARIFA; ARMANI, 2001, p. 56). Um clima socialmente construído que é mais quente que o seu entorno e que é incapaz de compensar a cada vez mais frequente baixa umidade do ar metropolitana e a poluição atmosférica trazida pelos eixos viários, prejudicando a qualidade de vida e a saúde da população.

\footnotetext{
11 Segundo Bartalini (2006, p. 91), os córregos ocultos são os cursos d'água capilares, muitas vezes anônimos, que canalizados desapareceram sob o chão das cidades.
} 
Para enfrentar esses e outros problemas, propusemos um plano de Infraestrutura Verde que, observando os comportamentos natural e atual da bacia hidrográfica e valendo-se do zoneamento ambiental baseado nos processos naturais e nas formas do relevo, espacializou as tipologias paisagísticas de modo a recuperar a funções ecossistêmicas que a bacia do córrego Água Preta perdeu com o adensamento da urbanização, notadamente sua capacidade de infiltração, evaporação, evapotranspiração, interceptação e armazenamento (retenção) da chuva.

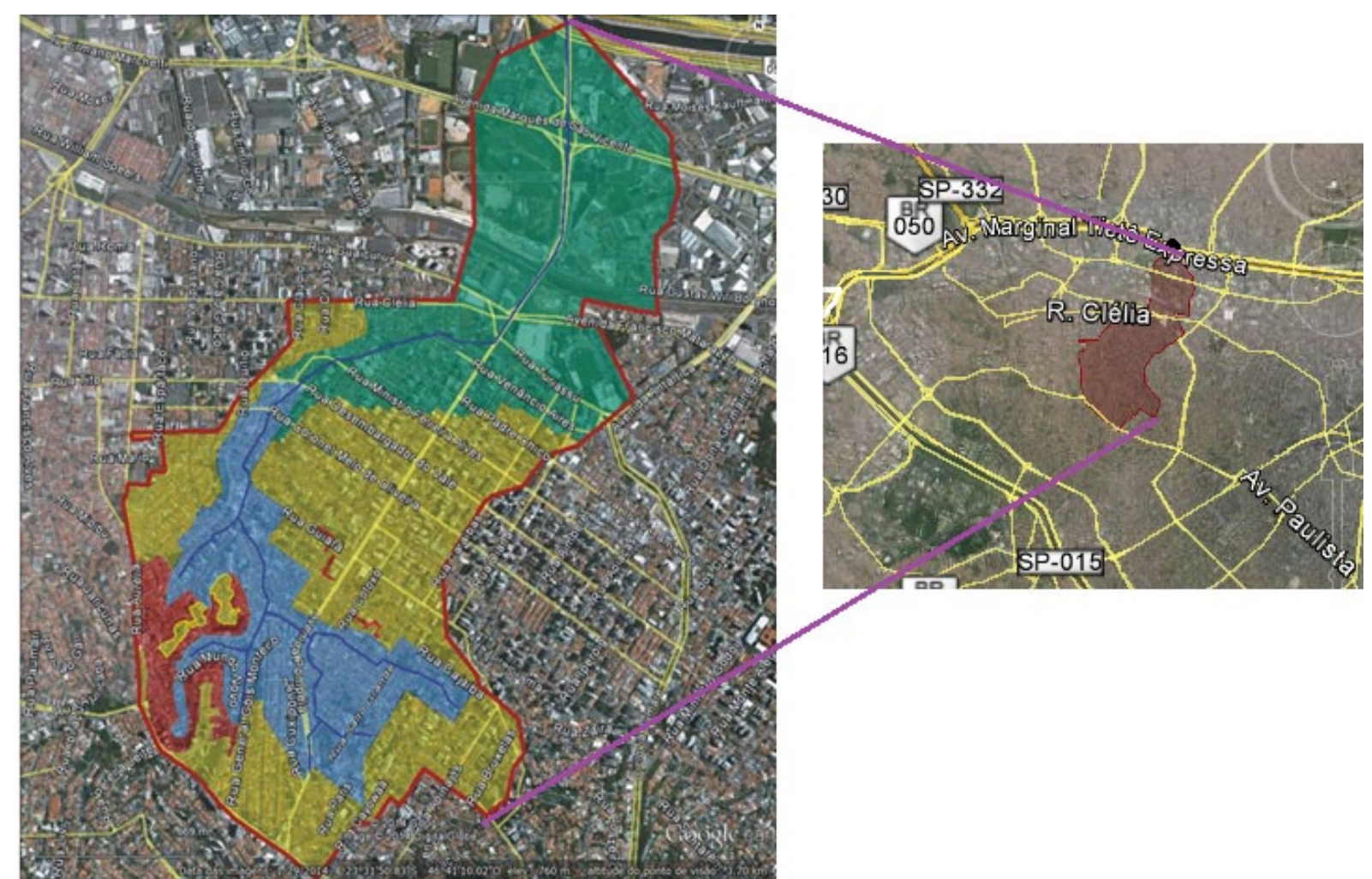

Áreas tabulares livres de inundação

Áreas ingremes das vertentes das altas colinas

Figura 12 - Zoneamento ambiental da Bacia do córrego Água Preta.

Área de nascentes

Fundos de vale

Elaboração do autor a partir de base do Google Earth.

Entende-se que a aplicação estratégica das tipologias propiciará o rearranjo temporal das vazões, retardando o escoamento superficial. A chegada da água da chuva aos canais de drenagem acontecerá em um período maior de tempo. Adicionalmente, a captura do escoamento superficial para infiltrá-lo e/ou transformá-lo em umidade do ar e biomassa, diminuirá o volume total do escoamento superficial. 


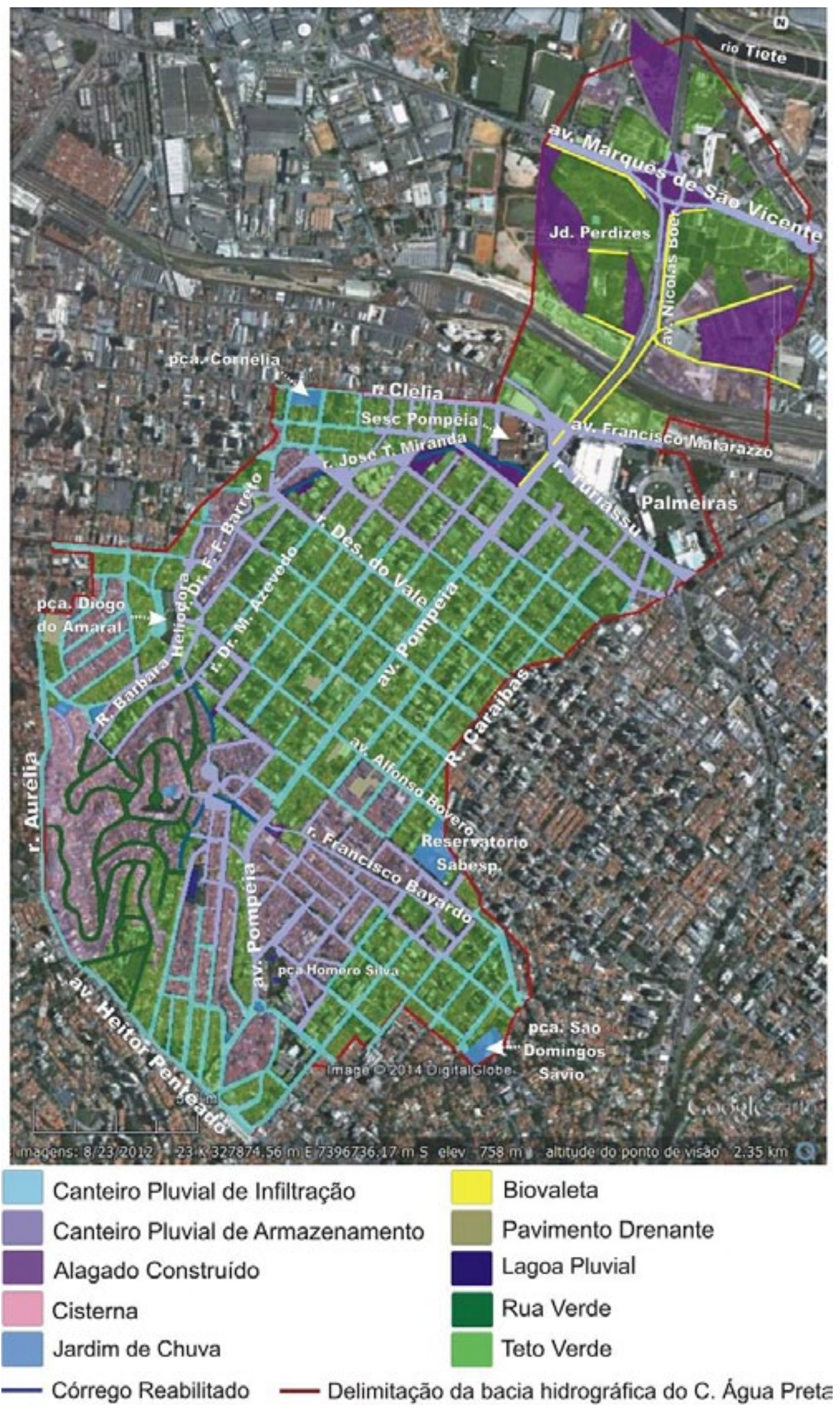

Figura 13 - A diretriz 10 espacializa as tipologias de acordo com os processos naturais predominantes em cada zona ambiental da bacia hidrográfica do córrego Água Preta. Elaborado pelo autor, sobre imagem do Google Earth. 
Além de reduzir a probabilidade de inundações, essa abordagem alternativa de drenagem urbana providenciará ganhos na qualidade das águas, permitindo à população, em curto prazo, uma reaproximação do córrego Água Preta, e em longo prazo, do próprio rio Tietê, já que a Infraestrutura Verde aqui proposta em 10 diretrizes $^{12}$ fará com que o Água Preta lhe entregue águas limpas, ao invés do atual mistura tóxica carreada pela chuva. $O$ retorno da água à paisagem também minimizará os efeitos das ilhas de calor, criando ainda habitats para a fauna, condições para o desenvolvimento de uma flora vigorosa, contribuindo para o fortalecimento de uma identidade local e a qualificação dos espaços públicos.

\section{CONSIDERAÇÕES FINAIS}

A Infraestrutura Verde fomenta (e também é resulta de) uma mudança profunda nas relações entre natureza e sociedade. Esse novo modelo de intervenção na paisagem entende que natureza e cidade não são entidades antagônicas. Ao contrário: a noção de serviços ambientais tão cara à Infraestrutura Verde evidencia que paisagens naturais/naturalizadas são importantes para a qualidade de vida no ambiente urbano.

Acreditamos que o método aqui proposto é uma contribuição teórica original ao tomar como referência a análise geomorfológica do saudoso professor brasileiro Aziz Ab'Saber e o Zoneamento Ambiental baseado no processos naturais, de Schutzer, como ponto de partida para a aplicação da Infraestrutura Verde.

Neste sentido, o relevo desponta como a variável importantíssima para o planejamento da Infraestrutura Verde e sua espacialização em áreas densamente urbanizadas.

12 As 10 diretrizes são: \#1-Incentivo à infiltração nas cabeceiras, Vila Pompéia e demais áreas planas; \#2-Rigoroso controle do escoamento superficial nas encostas; \#3-Armazenamento descentralizado e estratégico da água da chuva; \#4-Revisão das taxas de permeabilidade do zoneamento do plano estratégico da subprefeitura da Lapa; \#5- Criação do Parque Fluvial Córrego Água Preta; \#6-Recuperação do remanescente florestal do Morro do Cruzeiro; \#7-Arborização maciça na Vila Anglo Brasileira; \#8-Conexão entre baixo e médio curso, atualmente interrompida pela orla ferroviária; \#9-Criação de bairro-parque no baixo curso; \#10-Cultivar a grade verde. Para conhecer o plano em sua totalidade, consultar Bonzi, 2015. 


\section{REFERÊNCIAS}

AB'SÁBER, Aziz Nacib. O sítio urbano de São Paulo. In: Azevedo, Aroldo de. A cidade de São Paulo: estudos de geografia urbana. Vol I. São Paulo: Nacional, 1958.

Um conceito de geomorfologia a serviço das pesquisas sobre o quaternário. Universidade de São Paulo, Instituto de Geografia, 1969.

BARTALINI, Vladimir. A trama capilar das águas na visão cotidiana da paisagem. Revista USP n. 70. São Paulo: USP, 2006.

BENEDICT, Mark A.; MCMAHON, Edward T. Green Infrastructure: linking landscapes and communities. Washington: Island Press, 2006.

BONZI, Ramón S. Andar sobre Água Preta: a aplicação da Infraestrutura Verde em áreas densamente urbanizadas. Dissertação (Mestrado em Arquitetura e Urbanismo). Universidade de São Paulo: FAUUSP, 2015.

CORMIER, N; PELLEGRINO, P. Infra-Estrutura Verde: uma estratégia paisagística para a água urbana. Paisagem e Ambiente n. 25. São Paulo: FAUUSP, 2008.

FIREHOCK, Karen. Short history of the term Green Infrastructure and selected literature.Disponível em: <http://www.gicinc.org/PDFs/GI History.pdf>. Acesso em: 22/02/2013

FORMAN, R. T.; GODRON, M. Some general principles of landscape and regional ecology. In: Landscape ecology, v. 10, n. 3, p. 133-142, 1995.

FRANCE, Robert L. Wetland Design - Principles and Practices for Landscape Architects and Land-Use Planners. New York: W.N. Norton, 2003.

MENEGASSE-VELÁSQUEZ, L. N. Efeitos da Urbanização Sobre o Sistema Hidrológico: Aspectos da Recarga no Aqǘfero Freático eo Escoamento Superficial. Tese (Doutorado em Recursos Naturais e Hidrogeologia). Instituto de Geociências-USP, 1996.

PELLEGRINO, Paulo. Pode-se planejar a Paisagem? In: Paisagem e Ambiente n.13, p.159-180. São Paulo: FAUUSP, 2000. 
PINKHAM, R. 21stcentury water systems: scenarios, visions, and drivers. Snowmass: Rocky Mountain Institute, 1999.

Daylighting: New Life for Buried Streams. Snowmass: Rocky Mountain Institute, 2000.

SCHJETNAN, M;CALVILLO, J; PENICHE, M. Principios de diseño urbano/ambiental. Cidade do México: Árbol Editorial, 1997.

SCHUTZER, José Guilherme. Cidade e meio ambiente: a apropriação do relevo no desenho ambiental urbano.Dissertação (Mestrado em Arquitetura e Urbanismo) - Universidade de São Paulo: FAUUSP, 2004.

Cidade e meio ambiente: a apropriação do relevo no desenho ambiental urbano.São Paulo: Edusp, 2012a.

Dispersão urbana e apropriação do relevo na macrometrópole de São Paulo. Tese (Doutorado em Geografia). Universidade de São Paulo: FFLCH, 2012b.

Análise estratégica do relevo e planejamento territorial urbano: compartimentos ambientais estruturantes na macrometrópole de São Paulo. Revista LABVERDE, n. 5, p. 12-36, 2012c.

TARIFA, J. R.; ARMANI, G. Os climas urbanos. In: TARIFA, J.R.; AZEVEDO, T.R. (org.). Os climas na cidade de São Paulo - teoria e prática. São Paulo: GEOUSP, 2001.

TUCCI, C. Água no meio urbano. In: REBOUÇAS, BRAGA, TUNDISI. Águas doces no Brasil - Capital Ecológico, usos e conservação. São Paulo: Escrituras Editora, 2006. pp. 399-431.

ZANELLA, L. Plantas ornamentais no pós-tratamento de efluentes sanitários: wetlands-construídos utilizando brita e bambu como suporte. 2008. Tese. (Doutorado em Engenharia Civil, Saneamento e Ambiente). Universidade Estadual de Campinas. 